\title{
Evaluation of growth performance and intestine villi morphology of black sea trout (Salmo labrax Pallas, 1814) fed with different protein levels containing diets
}

\section{Farklı protein düzeyli diyetlerle beslenen karadeniz alabalığı (Salmo labrax Pallas, 1814)'nın büyüme performansı ve bağırsak villi morfolojisinin belirlenmesi}

\author{
Osman Tolga Özel1* \\ - Eyüp Çakmak' ${ }^{1}$ \\ ${ }^{1}$ Central Fisheries Research Institute, Trabzon, Turkey \\ ${ }^{2}$ Ahi Evran University, Faculty of Agriculture, Department of Animal Science, Kırşehir, Turkey \\ * Corresponding author: osmantolga.ozel@tarim.gov.tr
}

- İsa Coşkun²

- Ekrem Cem Çankırılıgil1

How to cite this paper:

Özel, O.T., Çakmak, E, Coşkun, I \& Çankırılıgil, E.C. (2018). Evaluation of growth performance and intestine villi morphology of black sea trout (Salmo labrax

Pallas, 1814) fed with different protein levels containing diets. Ege Journal of Fisheries and Aquatic Sciences, 35(2), 125-130. DOI:10.12714/egejfas.2018.35.2.04

\begin{abstract}
This study was conducted to determine changes in the growth performance and distal intestine villi morphology of juvenile Black Sea trout (Salmo labrax) fed diets with three different protein levels (40\%, $45 \%$ and $50 \%$ ). It was carried out in two separate sections; freshwater (RAS) and seawater. Juvenile Black Sea trout, having average initial weights of $3.44 \mathrm{~g}$ (freshwater) and $17.70 \mathrm{~g}$ (seawater), were fed for 90 days. WG, SGR, FCR and survival weren't affected by dietary treatment. However distal intestine villi length (VL), width (VW) and length to width ratio (VL/NW) were affected by dietary treatments. Villi length, width and length to width ratio in the fish fed with diet containing $50 \%$ protein in freshwater were found to be higher than those fed with other diets. Villi length in the fish fed with diet containing $50 \%$ protein in seawater was higher than those fed with other diets. Results showed that feeding with diets contained different protein levels did not effect on growth performance of Juvenile Black Sea trout, but affected on distal intestine villi morphology.
\end{abstract}

Keywords: Black Sea trout, growth, intestine, villi morphology

Öz: Bu çalışma, üç farklı protein düzeyi (\%40, \%50 ve \%55) içeren diyetlerle beslenen yavru Karadeniz alabalığı (Salmo trutta labrax)' nın büyüme performansı ve bağırsak villi morfolojisindeki değişimleri belirlemek için yapıımıştır. Çalışma tatlısu (kapalı devre) ve deniz suyu olmak üzere iki ayrı yetiştiricilik şartlarında yürütülmüştür. Başlangıç ağırlıkları $3.44 \mathrm{~g}$ (tatlısu) ve $17.70 \mathrm{~g}$ (deniz suyu) ortalamalarına sahip yavru Karadeniz alabalıkları 90 gün boyunca beslenmiştir. Ağırlık artışı, spesifik büyüme oranı, yem değerlendirme oranı ve yaşama oranı diyetsel uygulamalardan etkilenmemiş, bağırsak villi uzunluğu (VL), genişliği (VW) ve uzunluğun genişliğe oranı (VL/VW) ise diyetsel uygulamalardan etkilenmiştir. Tatısuda \%50 protein içeren diyetle beslenen balıkların VL, VW ve VL/NW değerleri diğer iki diyetle beslenenlerden daha yüksek bulunmuştur. Deniz suyunda ise $\% 50$ protein içeren diyetle beslenen balıkların VL değeri diğer iki diyetle beslenenlerden daha yüksek bulunmuştur. Bu sonuçlar, farklı protein düzeylerinin yavru Karadeniz alabalığının büyüme performansı üzerinde herhangi bir etkiye sahip olmadığı, ancak bağırsak villi morfolojisi üzerine etkiye sahip olduğunu göstermiştir.

Anahtar kelimeler: Karadeniz alabalığı, büyüme, bağırsak, villi morfoloji

\section{INTRODUCTION}

Black Sea trout (Salmo labrax Pallas, 1814) as a subspecies of the brown trout and an opportunistic ecotype is distributed at the Eastern Black Sea. This is an endemic species for Turkey. They spawn in freshwater, migrate to sea in smolt stage, and spend their adult stage in seawater, and migrate to freshwater to spawn again. Black sea trout have three different ecotypes: Species that migrate to the sea in the Black Sea basin, that don't migrate to the sea but resident in the stream, and that resident in lakes in the Black Sea Region are called "sea ecotype", "stream ecotype", "lake ecotype" respectively (Tabak et al. 2002). This species has become an important aquaculture species of Turkey in recent years with the works carried out by Central Fisheries Research Institute over the years.

Proteins are the major components of tissues and organs, the major structure of diverse enzymes and hormones, protect the organism against the environment, carry oxygen to the cells and carbon dioxide from the cells, and also an energy source 
for metabolic actions (Karabulut, 1991). Protein needs of fish is depending on such factors like feeding rates, genetic composition of fish, environmental conditions of rearing environment including water temperature, quality of water (Anonymous, 2017) and salinity along with age and size of fish (Ahmad et al. 2004), and amino acid composition of protein source (Somsueb, 2017). Ramezani, (2009) stated that protein requirement for salmonids varies between 40 and $50 \%$. Amoah, (2011) stated that optimum growth occurs when protein supplies about $40-50 \%$ of the energy requirements in carnivorous fish.

The gastrointestinal tract of fish consist of the mouth, oesophagus, stomach, pyloric ceaca, mid-intestine, distal intestine and the rectum (Merrifield et al. 2011). The gastrointestinal tract are responsible to storing food and water, processing ingested food and water and absorbing digested food and water, and excreting wastes (Jutfelt, 2006). The gastrointestinal morphology is related to feeding habits such as food components, food intake frequency along with body size, shape and species (Khojasteh et al. 2009). The intestines are among the most important organs of fish charged with digestion and absorption of ingested food. Thus, histologically examination of the digestive system especially intestine is quite important. With this way, the knowledge related to nutritional status of fish is can be obtained (Chowdhary et al. 2013; Yadav et al. 2014). The histological features of fish intestine can vary depending on abiotic and biotic factors (Khojasteh, 2012).

In sum, there is lack of knowledge still exist in the Black Sea trout's instestine histology. Only few studies carried out with Salmo labrax in this subjects (Cankiriligil et al. 2016, Özel et al 2017; Özel et al. 2018a). The aim of this study was evaluate to effect of the different protein levels on the growth and distal intestinal villi morphology of Black Sea trout. Our research will contribute to scientific community with revealing effects of different protein based diets and draw attention to Black Sea trout as an endemic and valuable species to aquaculture sector.

\section{MATERIALS AND METHODS}

\section{Fish, feeding trials and experimental diets}

The study was carried out at Central Fisheries Research Institute with two trial groups as trouts cultured in freshwater Recirculateing Aquaculture Systems (RAS) and cultured in open tank system with seawater. In these groups, the average initial weights were $3.44 \mathrm{~g}$ and $17.70 \mathrm{~g}$, and fish counts were 70 and 50 respectively. The fifth-generation (F5) juvenile Black Sea trout were used in both study. Every trial was carried out in triplicate. Fish were fed manually $3 \%$ (in freshwater) and $2 \%$ (in seawater) of their body weight per day at four times at 08:00, 12:30, 13:00 and 15:30 h. Feed amount was mathematically calculated every three days, and determined by weight increase every fifteen days. Water temperature was saved daily. The experiment lasted for 90 days. Water temperature in the freshwater and seawater were 13.9-17.5 $(15.3 \pm 0.32)^{\circ} \mathrm{C}$ and $7.5-13.5(10.5 \pm 1.76)^{\circ} \mathrm{C}$, respectively. Water in tanks was changed 24 times in a day. The cleaning of trail tanks was done by siphoning daily. Three experimental diets were formulated to contain protein at $40 \%, 45 \%$ and $50 \%$ levels using fish meal. Crude fat contents of the experimental diets were adjusted as $15 \%$. Ingredients and nutrient composition of all diets were shown in Table 1.

\section{Chemical analysis}

Proximate composition of diets were determined as three parallel. Moisture content and crude ash were carried out Horwitz, (2000). Crude protein was determined by the Kjeldhal procedure and nitrogen conversion factor set as 6.25 (AOAC, 2009). Finally, crude fat ratios were determined according to Folch et al. (1957).

\section{Performance parameters}

The growth performance of the fish was calculated in according to Ebrahimi and Ouraji, (2012).

Weight gain (WG) (\%) = [(final weight - initial weight) / initial weight $(\mathrm{g})] \times 100$

Specific growth rate (SGR) (\% body weight/day) $=[($ In final weight - In initial weight) /trial period (days)] × 100

Feed conversion ratio $(F C R)=$ Total feed intake $(\mathrm{g}) /$ Weight gain $(g)$ 100

Survival $(\%)=($ final number of fish $/$ initial number of fish $) \mathrm{x}$

\section{Intestine histomorphology}

Distal intestine samples were taken from intestine and cut into $1.5 \mathrm{~cm}$ pieces and placed into $10 \%$ formalin for further processing. Tissues sections were placed into tissue cassettes for dehydration process and were embedded in paraffin blocks, and subsequently cut $5-\mu$ thickness and placed on a slide. Each intestine histomorphologic tissue sample was prepared and stained with hematoxylin and eosin solution by using standard paraffin-embedding procedure. After embedding process, villi length and villi width were photographed and evaluated by using an image processing and analysis system (ZEN 2012 SP2) (Xu et al. 2003).

\section{Statistical analysis}

Data were analyzed by one-way analysis of variance (ANOVA). Differences between means were compared using Duncan's multiple range test. Differences were considered statistically significant at $P<0.05$. All statistical analyses were computed using SPSS 15.0. 
Table 1. Formulation and proximate composition of experimental diets (\%)

\begin{tabular}{lrrr}
\hline \multirow{2}{*}{ Ingredients } & & Diets & $\mathbf{5 0}$ \\
\cline { 2 - 4 } & $\mathbf{4 0}$ & $\mathbf{4 5}$ & 40 \\
Fish meal & 28 & 33 & 19 \\
Soybean meal & 19 & 19 & 14.5 \\
Chicken meal & 14.5 & 14.5 & 6.9 \\
Sunflower meal & 8.9 & 8.3 & 10 \\
Semolina flour & 19 & 15 & 7.1 \\
Fish oil & 8.1 & 7.7 & 2 \\
Wheat gluten & 2 & 2 & 0.20 \\
Vit mix & 0.20 & 0.20 & 0.15 \\
Mineral mix & 0.15 & 0.15 & 0,05 \\
Colin cloride & 0,05 & 0,05 & 0.1 \\
Vit C & 0.1 & 0.1 & 49.6 \\
Proximate composition & & 44.9 & 15.1 \\
Crude protein & 40.1 & 15.1 & 8.1 \\
Crude lipid & 15.0 & 7.3 & 6.4 \\
Ash & 6.7 & 5.7 & 3600 \\
Moisture & 5.2 & 3611 & \\
Metabolic energy (kcal/kg) & 3622 & & \\
\hline
\end{tabular}

\section{${ }^{1}$ Cod liver oil}

2Roche Performance Premix (Hoffman-La Roche, INC., Nutley, N.J., USA), composition per g of the vitamin mixture: vitamin A, 2645,50 IU; vitamin D3, 220,46 IU, vitamin E, 44,09 IU; vitamin B,12 13 mg; riboflavin,13,23 mg; niacin, 61,73 mg; d-pantothenic acid, 20,05 mg; menadione, 1,32 mg; folic acid, 1,76 mg; thiamin, $7,95 \mathrm{mg}$ and d-biotin, $0,31 \mathrm{mg}$.

3Bernhart Tomarelli salt mixture (ICN Pharmaceuticals, Costa Mesa, CA, USA), composition (g/100 g): calsium carbonate , 2.1; calsium phosphate dibasic, 73.5; citric acid, 0.27 ; cupric citrate, 0.046 ; ferric citrate, 0.558 ; magnesium oxide, 2.5 ; manganese citrate, 0.835 ; potassium iodide, 0.001 ; potassium phosphate dibasic, 8.1; potassium oxide, 6.8; sodium chloride, 3.06; sodium phosphate, 2.14; and zinc citrate, 0.133 .

\section{RESULTS}

\section{Growth performance and intestine histomorphology}

Results demostrated that fish growth wasn't significantly affected by dietary protein levels but intestine villi morphology was affected. Final weight, weight gain (WG), specific growth rate (SGR), feed conversion rate (FCR) and survival rate weren't affected by the dietary protein levels in both freshwater and seawater conditions $(P>0.05)$. In freshwater, however, as dietary protein levels increased, final weight, weight gain, SGR, FCR improved numerically. But this improvement was insignificant $(P>0.05)$. Intestine villi length $(\mathrm{VL})$, width $(\mathrm{VW})$ and length to width ratio (VL/VW) were affected by dietary treatments in both conditions. Villi length, width and length to width ratio in the fish fed with diet containing $50 \%$ protein in freshwater were found to be higher than those fed with other diets. VW and VL/VW in the fish fed with a diet containing $40 \%$ and $45 \%$ protein in freshwater was found to be similar to each other. Villi length in the fish fed with diet containing $50 \%$ protein in seawater was higher than those fed with other diets. Villi width in the fish fed with a diet containing $40 \%$ and $50 \%$ protein in seawater was found to be similar to each other. In both freshwater and seawater conditions, the intestine villi length significantly increased with increasing dietary protein levels.

Results are summarized in Table 2 and 3. Histological photographs of distal intestine were shown in Figure 1 and 2.

Table 2. Growth parameters and distal villi morphology of juvenile Black Sea trout fed diets with three different protein levels for 12 weeks in freshwater

\begin{tabular}{lrrr}
\hline & & \multicolumn{1}{c}{ Freshwater $\left(\mathbf{1 5 . 3 ^ { \circ } \mathrm { C } )}\right.$} \\
\cline { 2 - 4 } Growth parameters & \multicolumn{1}{c}{$\mathbf{4 0 \%}$} & $\mathbf{4 5 \%}$ & $\mathbf{5 0 \%}$ \\
\hline Initial weight $(\mathrm{g})$ & $3.43 \pm 0.01$ & $3.44 \pm 0.01$ & $3.44 \pm 0.01$ \\
Final weight $(\mathrm{g})$ & $21.37 \pm 1.48$ & $21.41 \pm 0.77$ & $22.63 \pm 0.17$ \\
Weight gain $(\%)$ & $522.66 \pm 44.04$ & $522.92 \pm 21.40$ & $558.82 \pm 5.31$ \\
SGR $(\%)$ & $2.02 \pm 0.08$ & $2.03 \pm 0.04$ & $2.09 \pm 0.01$ \\
FCR & $1.37 \pm 0.18$ & $1.32 \pm 0.03$ & $1.20 \pm 0.04$ \\
Survival rate $(\%)$ & $86.67 \pm 5.41$ & $90.48 \pm 2.18$ & $87.62 \pm 2.18$ \\
\hline Villi Morphology & & & $901.79 \pm 120.38^{\mathrm{a}}$ \\
\hline VL $(\mu \mathrm{m})$ & $626.16 \pm 102.04^{\mathrm{c}}$ & $707.60 \pm 114.77^{\mathrm{b}}$ & $129.78 \pm 30.08^{\mathrm{a}}$ \\
VW $(\mu \mathrm{m})$ & $111.36 \pm 21.61^{\mathrm{b}}$ & $114.92 \pm 20.66^{\mathrm{b}}$ & $7.27 \pm 1.82^{\mathrm{a}}$ \\
VL/NW & $5.82 \pm 1.49^{\mathrm{b}}$ & $6.31 \pm 1.37^{\mathrm{b}}$ & \\
\hline
\end{tabular}

Means with different superscript letters in a row are significantly different $(\mathrm{P}<0.05)$ 
Table 3. Growth parameters and diatal villi morphology of Black Sea trout juveniles fed diets with three different protein levels for 12 weeks in seawater

\begin{tabular}{|c|c|c|c|}
\hline \multirow[b]{2}{*}{ Growth parameters } & \multicolumn{3}{|c|}{ Seawater $\left(10.5^{\circ} \mathrm{C}\right)$} \\
\hline & $40 \%$ & $45 \%$ & $\mathbf{5 0 \%}$ \\
\hline Initial weight $(\mathrm{g})$ & $17.70 \pm 0.02$ & $17.73 \pm 0.01$ & $17.68 \pm 0.02$ \\
\hline Final weight $(g)$ & $55.39 \pm 1.68$ & $55.41 \pm 3.28$ & $55.23 \pm 2.27$ \\
\hline Weight gain (\%) & $212.97 \pm 9.70$ & $228.78 \pm 18.36$ & $212.92 \pm 12.98$ \\
\hline SGR (\%) & $1.26 \pm 0.03$ & $1.32 \pm 0.06$ & $1.27 \pm 0.05$ \\
\hline FCR & $1.61 \pm 0.12$ & $1.48 \pm 0.04$ & $1.55 \pm 0.12$ \\
\hline Survival rate $(\%)$ & $96.67 \pm 4.16$ & $98.00 \pm 3.46$ & $98.00 \pm 2.00$ \\
\hline \multicolumn{4}{|l|}{ Villi Morphology } \\
\hline $\mathrm{VL}(\mu \mathrm{m})$ & $531.05 \pm 104.45^{c}$ & $638.28 \pm 100.12^{b}$ & $788.44 \pm 104.26^{a}$ \\
\hline $\mathrm{VW}(\mu \mathrm{m})$ & $125.45 \pm 34.44^{a b}$ & $116.17 \pm 24.39^{b}$ & $127.26 \pm 14.02^{\mathrm{a}}$ \\
\hline VL/NW & $4.44 \pm 1.23^{b}$ & $5.74 \pm 1.66^{\mathrm{a}}$ & $6.27 \pm 1.17^{a}$ \\
\hline
\end{tabular}

Means with different superscript letters in a row are significantly different $(\mathrm{P}<0.05)$

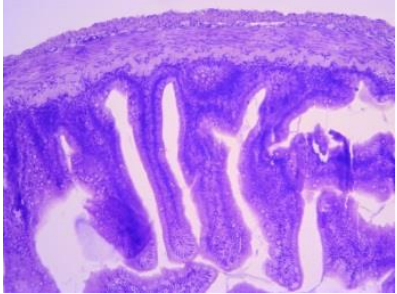

(A)

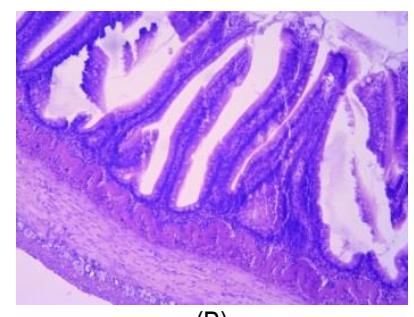

(B)

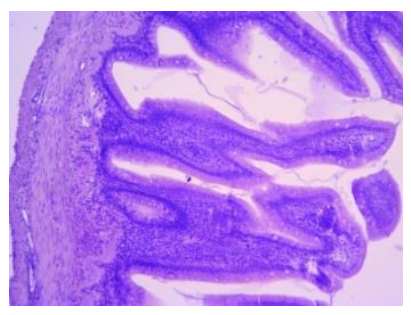

(C)

Figure 1. Distal intestine villi histology of Black Sea trout fed diets with $40 \%(A), 45 \%(B)$ and $50 \%(C)$ protein levels in freshwater $(4 x, H \& E)$

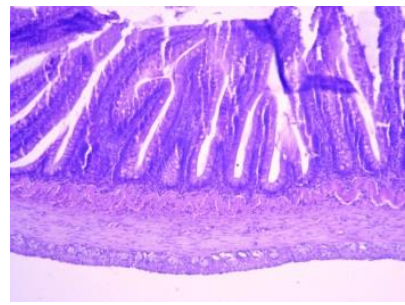

(D)

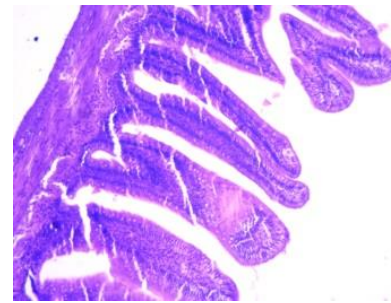

(E)

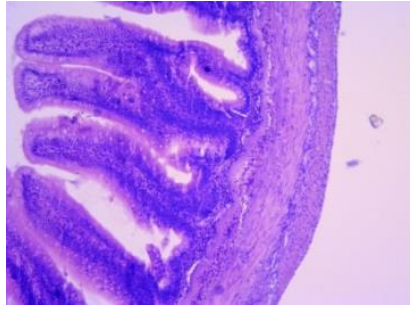

$(\mathrm{F})$

Figure 2. Distal intestine villi histology of Black Sea trout fed diets with $40 \%(D), 45 \%$ (E) and $50 \%$ (F) protein levels in seawater. (4x, H\&E)

\section{DISCUSSION}

In a previous study, FCR and SGR in juvenile Caspian Brown trout (Salmo trutta caspius) fed on diets containing 45 and $50 \%$ protein were better than those of $55 \%$ protein (Ramezani, 2009). An additional previous study, juvenile Arctic charr (Salvelinus alpinus) had highest growth rate when fish fed with high dietary protein level (39.89\% CP) (Amoah, 2011). Protein requirements for maximum growth of Arctic charr, Atlantic salmon, Chinook salmon, Coho salmon, Sockeye salmon and rainbow trout were found as $39 \%, 55 \%$ (or 45 ), $40 \%, 40 \%, 45 \%$ and $40 \%$, respectively, depending on protein sources in diet (Lall and Anderson, 2005). In present study, weight gain, feed conversion ratio and specific growth rate weren't affected by dietary protein levels (40, 45 and 50\%). According to this results, in both freshwater and seawater conditions, diets of juvenile Black Sea trout can contain the protein $40-50 \%$. It can be said that this results were similar to those in salmonids described above. Also, in the present study, it was found that Black Sea trout obtained a growth nearly 5 fold in weight at the end of 90-days trial period in freshwater conditions. A similar result was reported by Özel et al. (2018b). The growth of brown trout, which is rather slow in fresh water, is substantially increased in sea water (Quillet et al. 1992). In the present study, however, it was found that these species obtained a growth nearly 2 fold in weight at the end of 90-days trial period in seawater. This result was quite low compared to freshwater. This may arise from decrease of feed intake. Because fish were fed $2 \%$ of their body weight during experiment. Whereas were fed $3 \%$ in freshwater. Also seawater temperature was low compared to freshwater. Moreover, fish may have been exposed to tank and smoltification stress due to keeping in tank environment during experiment. Similarly, Dosdat et al. (1997) stated that growth rate of Brown trout was 
decreased during first 20 days after they transferred to seawater due to large decrease in feed intake. Lower growth rate can be explain to lesser domestication associated with feeding behavior of brown trout in small tanks. The most significant growth rate as 0.98 was recorded in $27 \mathrm{~m}^{3}$ sea cages owing to less stress levels. The reason for that is these fish fed with equivalent diet (52\% protein and $18 \%$ ) with high feeding ratio as $1 \%$ per body weight by day.

In previous studies, Yadav et al. (2014) found that diets with fish oil, soybean oil, linseed oil and beef tallow allowed increase in number of intestine villi of Asian catfish (Clarias batrachus), Zaki et al. (2015) found that dietary chitosan incorporated into feed formulation on the intestine morphology of Sea bass (Dicentrarchus labrax) increased the villus height in duedonum and jejenum, Heidarieh et al. (2013) found that aloe vera incorporated in the Rainbow trout (Oncorhynchus mykiss) feed increased the villus length and decreased the villus width in proximal intestine. Also Santigosa et al. (2011) stated that vegetable based feeding of fish effects to intestine histology. These results shows that intestine villi morphplogy can be affected by dietary treatments. Raskovic et al. (2011) stated that intestine histology can vary due to the selected species and ingested feed. In present study, the villi length (VL), width (VW)

\section{REFERENCES}

Ahmad, M.H., Abdel-Tawwab, M., \& Khattab, Y.A.E. (2004). Effect of dietary prote In levels on growth performance and protein utilization in Nile tilapia (oreochromis niloticus I.) with different initıal body weights. The sixth international symposium on tilapia in aquaculture, Manila, Philippine.

Anonymous., (2017). The Importance of Amino Acids in Fish Farming. Date accessed: 09.10.2017

Amoah, Y.T. (2011). Effect of dietary protein levels on growth and protein utilization in juvenile arctic char (Salvinus alpinus). United Nations University Fisheries Training Programme, Iceland (final Project). http://www.unuftp.is/static/fellows/document/yaa11prf.pdf

AOAC. (2009). Food analysis, Vol. Chapt. ed. Gaithersburg.

Cankiriligil, E.C., Cakmak, E., \& Ozcan Akpınar, I. (2016). Histological Development of the Digestive Tract of Black Sea Trout (Salmo trutta labrax PALLAS, 1811) During Larval Ontogeny, in: 41th CIESM Congress Living Resources \& Marine Ecosystems Committe. p. 330.

Chowdhary, S., Srivastava, P.P., Jena, J., Yadav, A.K., Dayal, R., Mishra, S. \& Srivastava, S.M. (2013). Histological studies of the intestine in threatened Asian catfish (Clarias batrachus) fingerlings fed with animal or plant origin protein blended with glucosamine. International Journal of Fisheries and Aquatic Studies, 1(2), 50-55.

Dosdat, A., Metailler, R., Desbruyeres, E., \& Huelvan, C. (1997). Cornparison of brown trout (Salmo trutta) reared in fresh water and sea water to freshwater rainbow trout (Oncorhynchus mykiss) : 1. Growth and nitrogen balance. Aquat. Living Resource, 10(3), 157-167.

Ebrahimi, G., and Ouraji, H. (2012). Growth performance and body composition of kutum fi ngerlings, Rutilus frisii kutum (Kamenskii 1901), in response to dietary protein levels. Turk J Zool, 36 (4), 551-558

Folch, J., Lees, M., and Sladane-Stanley, G.H.A. (1957). Simple method for the isolation and purification of total lipids from animal tissue. J. Biol. Chem 226, 497-509.

Heidarieh, M., Mirvaghefi, A.R., Sepahi, A., Sheikhzadeh, N., Shahbazfar, A.A., \& Akbari, M. (2013). Effects of dietary aloe vera on growth performance skin and gastrointestine morphology in Rainbow trout (Oncorhynchus and length to width ratio (VL/VW) significantly affected by dietary protein levels in both freshwater and seawater. In both conditions, VL and VW of fish fed with $50 \%$ protein were higher than those fed with $40 \%$ and $45 \%$ protein. Similarly, MichelParra et al. (2007) found that small intestine villi length of tilapia (Orechromis aureus) fed with $50 \%$ protein containing diets was higher than those fed with $40 \%$ protein. Our results show that there are the positive effects of different dietary protein levels on the distal intestine villi morphology.

Present study suggests that feeding with diets containing different protein levels of juvenile Black Sea trout did not effect on growth directly, but had on distal intestine villi structure. Besides, in order to obtain more detail knowledge about protein requirements of Black Sea trout, narrower $(<40 \%)$ and wider $(>50 \%)$ ranges should be studied, and this ranges should be studied at different water temperature, production systems and water sources with different sized fish. Also it should be search effects of different diets on intestine villi morphology.

\section{ACKNOWLEDGEMENTS}

We would like to thank the support given by the researchers in the project "Determination of nutrition requirements of Black Sea trout (Salmo labrax Pallas, 1814)"

mykiss). Turkish Journal of Fisheries and Aquatic Sciences, 13, 367-373. DOI: 10.4194/1303-2712-v13-2-20.

Horwitz, W. (2000). Official methods of analysis of AOAC international (Oma). Education Gaithersburg.

Jutfelt, F. (2006). The Intestinal Epithelium of Salmonids. Department of Zoology, Zoophysiology Göteborg University.

Karabulut, A. (1991). Animal feeding physiology and metabolism course note. Uludag Univesity, Faculty of Agriculture, Bursa, Turkey.

Khojasteh, S.M. B., Sheikhzadeh, F., Mohammadnejad, D., \& Azami, A. (2009). Histological, Histochemical and Ultrastructural Study of the Intestine of Rainbow Trout (Oncorhynchus mykiss). World Applied Sciences Journal 6 (11), 1525-1531.

Khojasteh, S.M.B. (2012). The morphology of the post-gastric alimentary canal in teleost fishes: a brief review. International Journal of Aquatic Science, $3(2)$.

Lall S.P. \& Anderson S. (2005) Amino acid nutrition of salmonids: Dietary requirements and bioavailability. In: Montero D. (ed.), Basurco B. (ed.), Nengas I. (ed.), Alexis M. (ed.), Izquierdo M. (ed.). Mediterranean fish nutrition. Zaragoza: CIHEAM, (2005). p. 73-90. (Cahiers Options Méditerranéennes; n. 63). Workshop on Mediterranean Fish Nutrition, 2002/06/01-02, Rhodes (Greece)

Michel-Parra, J.G., Orozco Hernandez, J.R., Ruiz Garcia, I.J. \& Montanes Valdez, O.D. (2007). Effect of protein level on Alevins growth and intestinal villi development of Tilapia (Orechromis aureus). Journal of Fisheries International, 2(3), 211-213.

Merrifield, D.L., Olsen, R.E., Myklebust, R. \& Ring ø, E. (2011). Dietary Effect of Soybean (Glycine max) Products on Gut Histology and Microbiota of Fish. INTECH Open Access Publisher.

Quillet, E., Faure, A., Chevassus, B., Krieg, F., Harache, Y., Arzel, J., Metailler, R. \& Boeuf, G. (1992). The potential of brown trout (Salmo trutta L.) for mariculture in temperate waters. Presented at Study course on aquaculture of arctic charr and brown trout, Reykjavik, ISL (1991-08-16 1991-08-18). http://prodinra.inra.fr/record/160662. 
Özel, O.T., Coşkun, I. \& Çakmak, E. (2018a). Intestine Villi Morphology of Black Sea Trout (Salmo labrax Pallas, 1814). LimnoFish, 4(1), 42-46. DOI: 10.17216/LimnoFish.365434

Özel, O.T., Çakmak, E. \& Coşkun, I. (2017). Intestine Villi Morphology of Black Sea Trout (Salmo trutta labrax Pallas, 1811): In Seawater and After Freshwater Transfer. 1st International Symposium on Limnology and Freshwater Fisheries. 04-06 October 2017, Isparta.

Özel, O.T., Çakmak, E. \& Öztürk, E. (2018b). Effects of Alternative Oil Sources on Growth Performance, Lipid Metabolism and mRNA level of Some Genes in Juvenile Black Sea Trout (Salmo trutta labrax Pallas,1811). Turkish Journal of Fisheries and Aquatic Sciences, 18, 891-903. DOI: 10.4194/1303-2712-v18-7-07

Ramezani, H. (2009). Effects of Different Protein and Energy Levels on Growth Prformance of Caspian Brown Trout, Salmo trutta caspius (Kessler, 1877) Journal of Fisheries and Aquatic Science. DOI: $10.3923 /$ fas.2009.203.209

Raskovic, B.S., Stankovic, M.B., Markovic, Z.Z. \& Poleksic, V.D. (2011). Histological methods in the assessment of different feed effects on liver and intestine of fish. Journal of Agricultural Sciences, 56(1), 87-100. DOI: 10.2298/JAS1101087R

Santigosa, E., García-Meilan, I., Valentin, J.M., Perez-Sanchez, J., Medale, F., Kaushik, S. \& Gallardo, M.A. (2011). Modifications of intestinal nutrient absorption in response to dietary fish meal replacement by plant protein sources in sea bream (Sparus aurata) and rainbow trout (Onchorynchus mykiss). Aquaculture 317(1-4), 146-154

DOI: 10.1016/j.aquaculture.2011.04.026

Somsueb, P. (2017). Protein and energy requirement and feeding of fish. http://citeseerx.ist.psu.edu/viewdoc/download;jsessionid=23164878DB26 11BBD42448A6F2AE045B?doi=10.1.1.526.3067\&rep=rep1\&type=pdf. Date accessed: 09.10.2017.

Tabak I., Aksungur M., Zengin M., Yılmaz C., Aksungur N., Alkan A., Zengin B., \& Misır D.S. (2002). Project for the investigation of the cultural feasibility and the determination of the biotechnological properties of the Black Sea trout (Salmo trutta labrax, Pallas 1811). Final report. General Directorate of Agricultural Research and Policies. 98/12/01/007. p. 173.

Yadav, A.K., Srivastava, P.P., Chowdhary, S., Lakra, W.S., Shrivastava, P., \& Dayal, R. (2014). Histological alterations in the intestine of threatened Asian catfish, Clarias batrachus fed with different types of fats through semi-purified diets. Advances in Applied Science Research, 5(2), 35-41.

Xu Z.R., Hu C.H., Xia M.S., Zhan X.A., \& Wang M.Q. (2003). Effects of dietary fructooligosaccharide on digestive enzyme activities, Intestinal microflora and morphology of male broilers, Poultry Science, 82, 1030- 1036.

Zaki, M.A., Salem, M.A., Gaber, M.M. \& Nour, A.M. (2015). Effect of chitosan supplemented diet on survival, growth, feed utilization, body composition \& histology of Sea bass (Dicentrarchus labrax). World Journal of Engineering and Technology, 3, 38-47. DOI: 10.4236/wjet.2015.34C005 